\title{
How an academic library worked during the COVID-19 pandemic
}

\author{
Ane Landoy \\ Academic Librarian \\ University of Bergen Library \\ E-mail ane.landoy@uib.no \\ Trude Færevaag \\ Academic Librarian \\ University of Bergen Library \\ E-mail trude.ferevaag@uib.no
}

In this paper, we will investigate how an academic library, the University of Bergen Library in Norway, handled the challenges following the Covid-19 pandemic when the University of Bergen closed the campus on short notice and the Library immediately had to go fully digital in all its services to academics and students. The academics and students were helped by more and automated access to electronic books and services, and we show the numbers of usage. The e-mail and chat-functions were expanded, with librarians working from home. As for the Library staff, having to start working from home offices with less than ideal infrastructure, the main issues were missing their colleagues. How did the Library return to (almost) normal services?

Keywords: Academic library, Norway, Covid-19, Digital Library

\section{The National Library of Romania and its environment: competitors and users: an introduction}

A few words as a background about the University of Bergen and its library: University of Bergen is located in Bergen, Norway's second largest city, located on the West Coast of Norway. The University of Bergen (UiB) is an internationally recognised research university. Academic diversity and high quality are fundamental, and $\mathrm{UiB}$ is the most cited university in Norway.

There are seven faculties at $\mathrm{UiB}$ and there are close to 18500 students at the university. Around 2000 of these are international students. More than 4000 faculty and staff are employed by the UiB. The library presents itself: "The University Library is a public research library at the University of Bergen (...) The main task of the library is to provide information and documentation services for research, teaching and dissemination at the University of Bergen. It also serves other institutions and users, including collaboration with local, national, and international partners. The library is open to the general public" (UB 2020).

Also: "The holdings of the University Library have been developed to serve research and teaching at the university. The library houses special collections such as photos, manuscripts, newspapers and maps. (...) A variety of databases and digital journals, to which the library subscribes, are also searchable online via the university network. (UB 2020)"

1.2 On COVID-19

Coronavirus refers to a family of viruses. COVID-19 - or Coronavirus Disease - is the infectious disease caused by a newly discovered type of coronavirus. Most people infected with the COVID-19 virus will experience mild to moderate respiratory illness and recover without requiring special treatment. Older people, and those with underlying medical problems are more likely to develop serious illness. (IFLA 2020)

Revista Română de Biblioteconomie şi Ştiința Informării = Romanian Journal of Library and Information Science ISSN 2559-5490, ISSN-L 1841-1940 • Volume 16 Issue 12020 pp. 2-12 https://doi.org/10.26660/rrbsi.2020.16.1.2

This work is licensed under a Creative Commons Attribution-NonCommercial-NoDerivatives 4.0 International License 
According to WHO, the COVID-19 virus spreads primarily through droplets of saliva or discharge from the nose when an infected person coughs or sneezes (IFLA 2020).

\subsection{On COVID-19 and libraries}

IFLA, the International Federation of Library Association, the global organisation for libraries, collects and publishes information and advice on how libraries can cope with the corona situation, and how to continue working when libraries are closed down, as they have been in many countries. A key question has been around the risk of infection through contact with materials carrying coronavirus, or from computer equipment. In many situations, access to computers is seen as essential, and exceptions have been made to library closures in order to allow this, while implementing tough rules designed to limit the risk.

Given that close physical contact appears to be the primary means of catching the virus, a core response has been 'social distancing' - keeping a safe distance between individuals in order to reduce the risks of the virus passing from one person to another. Coughing, sneezing, and even talking tends to mean that potentially contagious droplets are emitted into the air. Libraries of all sorts from around the world have been working hard to provide access to collections and services remotely, often investing time and effort in updating websites and computer systems in order to deal with demand. While many libraries already had a strong digital presence, many others have now moved to create one in order to continue serving members (IFLA, 2020).

Many libraries are seeing a major increase in interest in digital resources and have promoted their digital services, and there have also been major efforts to boost access to eBooks. In addition, a lot of publishers and vendors have taken helpful initiatives, by providing open access, especially to materials related to COVID-19. Others have facilitated access by making it easier to log-in and access materials from outside of official networks (IFLA 2020).

Moves towards the reopening of libraries were increasingly on the agenda as countries look to lift broader restrictions. One step being taken to reduce risks is to limit the number of people in the library at any one time. This makes it easier to maintain social distance. Some efforts globally include giving users specific times when they can come to the library to collect books, limiting concentration of users, f. ex. by keeping a number of areas (children's reading areas, meeting rooms, self-study areas) inaccessible. Measures also include removing some furniture including access to computer and limiting the time spent in the library. In some countries, services are provided outside the buildings and opening time is limited to particular groups (IFLA 2020).

The libraries have also worked hard to promote hygienic measures. Underlying is the need to keep staff, but also patrons, safe.

This has also been the concern of the Norwegian Library Association, who put together a set of guidelines for libraries, focusing on three main points (NBF 2020):

A) Sick persons should not be present.

B) Good hygiene and cleaning

C) Reduced contact between persons

The guidelines cover issues such as "regulations for staff", "opening hours", "staffing", "services for and contact with users", "numbers of visitors", "regulations for users", "limited use of the library" and "use of equipment in the library room". These guidelines were developed as a result of insecurity, especially among leaders of the public libraries (of which there are many small libraries with only one - two staff in Norway), and the lack of adequate help from the National Library of Norway, who mainly said: 
"Decisions related to health issues in connection with local library operations must be made in each municipality in consultation with health authorities. These decisions must be based on guidelines provided by the Institute of Public Health and information from the government. This includes questions about contact with the public and about infection". (NB 2020)

1.4 On Norwegian students and academics under COVID-19

The physical closure of Norwegian universities from March 12 had immediate and direct consequences for nearly 280,000 students and more than 38,000 employees. However, the authorities and the sector itself have agreed that the activities should be maintained to the greatest possible extent, even if the physical presence is excluded or severely limited. This has created an urgent and massive need for alternative solutions, both for teaching, guidance, research, dissemination and administration. The main question is how well the sector has handled this major change.

Almost two months after the institutions were closed, there is evidence of adaptability. We do not need to go further back than to August 2018, where both Universities Norway and several university rectors acknowledged that the higher education sector is a "super-thankship" that is stuck in old forms of learning. A survey from 2018 (Støren and Nesje, 2018) showed that traditional lectures were still the most widely used teaching form at Norwegian educational institutions, and that little has happened since the early 2000s. The contrast is high with the research and higher education minister's message to the sector on March 19, 2020, where he says he is "insanely impressed with everything you (the UoH sector) are doing in the face of the crisis the country is in". The digital teaching tool Zoom has been taken in large-scale use, a number of doctoral dissertations have been presented digitally and researchers are communicating with Norwegian and foreign colleagues digitally.

For an academic library, students and academics are the main user groups, and several surveys have been done on how scholars and students are experiencing the situation with closed campus, as was the situation in Norway from 12. March 2020, and digital teaching.

One of the subjects with a large number of students, who is also a Centre of Excellence in teaching is BioCEED. They performed a survey and found indications that the transition to only digital teaching in some way has gone quite well - for quite a lot of students, teachers and courses. However, there are also considerable challenges with the current situation. Many students receive less organized teaching both in terms of quantity and quality. Communication is essential to ease worry and to maintain progression and motivation. Organized teaching is important to ensure a structure and encourage contact. However, the students indicate that they want digital teaching to continue after opening of campus - as a supplement to campus teaching. (BioCeed 2020)

The same results were found in a survey done by the Centre of Excellence in Law, CELL, at the University of Oslo, and a survey done at the Faculty of humanities (Department of History): for example 78 per cent of the Bergen history students responded that they think the study situation has deteriorated after the shutdown. $70 \%$ of students responded that their efforts have been poorer, and 32 percent say that the shutdown has led to far worse study effort (CELL 2020; UiB 2020).

An interesting feature of the students' responses is that the library and lack of library facilities are not mentioned at all, and there are no library relevant questions in the surveys.

\subsection{Research questions and methodological issues}

We will investigate how the University of Bergen Library in Norway, handled the challenges following the Covid-19 pandemic when the university closed the campus on short notice and the Library immediately had to go fully digital in all its services. What were the consequences for services to academics and students? What were the consequences for the Library staff? What existing systems and structures were used, and what new ones were implemented? And how did the Library return to (almost) normal services? These are the questions we will look closer at. 
The main data will come from experiences during the pandemic, and from newspapers and websites, both before and after March $13^{\text {th }}$. We will also refer to findings from surveys done, in order to investigate how a large number of staff and students respond to questions about their wellbeing. We expect this mixed methods approach to yield a richer and more diverse picture of this extreme situation.

2. What existed already in digital format?

Returning to the University of Bergen Library, when COVID-19 closed the libraries and all buildings on campus, what was already in place in the digital library?

Like all Norwegian academic libraries, University of Bergen Library has for many years invested heavily in electronic books and journals, and has in 2019: 465.000 electronic books (1 million printed), and 31.000 unique titles of electronic journals ( 800 printed). The number of electronic books and journals is growing, following a decision by the Board of the University in the 1990s. In our experience, the acceptance of journals in electronic format has been almost universal, especially among the academic staff.

The university has also supported the development and implementation of "Litteraturkiosken", an electronic system for accessing book chapters and journal articles from paper format for required reading literature, and this is also well accepted and used by the students. The Litteraturkiosken is connected to the digital reading list system, making it easy for students to move from the reading list to the literature in digital format.

When it comes to electronic books, however, the acceptance and usage is lower, especially among students, in line with findings from multi-national surveys. (Gastinger, Landøy, Repanovici, 2015; Landøy, Færevaag, 2019; Mizrachi et al, 2018)

The Library had already implemented user oriented web pages, containing different kinds of instructions in written and video format. The web-pages were both general and subject specific, and covered situations from "how to use the library catalogue" to "how to write your $\mathrm{PhD}$ ".

A chat-function, implemented from 2012 was under evaluation in the fall term in 2019, and a decision was made to test out using a newly opened help function for the entire university instead of continuing with the library chat. When COVID-19 struck, the library chat was immediately reopened, and opening hours were extended. The chat uses the software Zopim / Zendesk chat (https://www.zopim.com/).

The software is easy to use for any library staff. There is a rota of librarians responding to inquiries, and the first in the morning also checks if there is anything in the history (i.e. questions that came in when the chat is not manned). The service is normally manned Monday to Friday 10 am to $15(3 \mathrm{pm})$ and patrons can also leave messages after scheduled hours.

The University of Bergen Library is organisationally and geographically divided in six libraries and a department of special collections. All the units have their own dedicated e-mail address, and there was already a system in place for replying to the e-mails. There is also a dedicated joint e-mail address for reporting problems connected to the library catalogue and off-campus access to electronic literature. Due to the geographically spread libraries the library had already slowly started a transition toward more digital meetings.

A popular service for PhDs and researchers is called "Shut up and write!" The concept entails researchers bringing their laptops to a meeting room in the library building at a set time. After an introductory round around the table, where people explain what they are doing that day, they write (or read, or revise) in quiet for 45 minutes. There is a 15 minute break where talking and discussion is allowed, before another 45 minutes period. This may go on for one more round. There are academic librarians present to facilitate, and to respond to questions during the breaks. 
The Library has also started experimenting with digital teaching and library trainings, but this will not be discussed in this paper, as the library training sessions are not scheduled for the period between late March and Mid-June (the late part of the spring term).

3. What happened?

3.1 The first full closure, March $12^{\text {th }}-$ April $20^{\text {th }}$ : The library buildings were also closed for library staff (working from home offices).

Books and journals:

The Library was already almost fully digital regarding journals, and started subscribing to a "get-it-now"-service for journal articles that needed interlibrary loan services. The articles were delivered in pdf to the patrons' e-mails within a couple of hours after a request through normal channels (library system or library e-mail). This service was not marketed particularly, and in the first ten weeks 86 articles were acquired through this service.

When the library buildings closed and the printed books became unavailable for the patrons, the Library offered access to more electronic books. Some of the books that the Library had already purchased or subscribed to were opened for more concurrent users. This was an initiative from the publishers or vendors. Also, the Library set up an online user-initiated book purchasing service where users could choose among an additional 450.000 electronic books. This service was marketed through the Library social media, and the books were searchable through the library catalogue. The service was set up with IP-identification, and the Library already had VPN and proxy server, so it was quite easily available for academics and students from their home offices and remote study work places.

\section{Weekly costs of user initiated purchases}

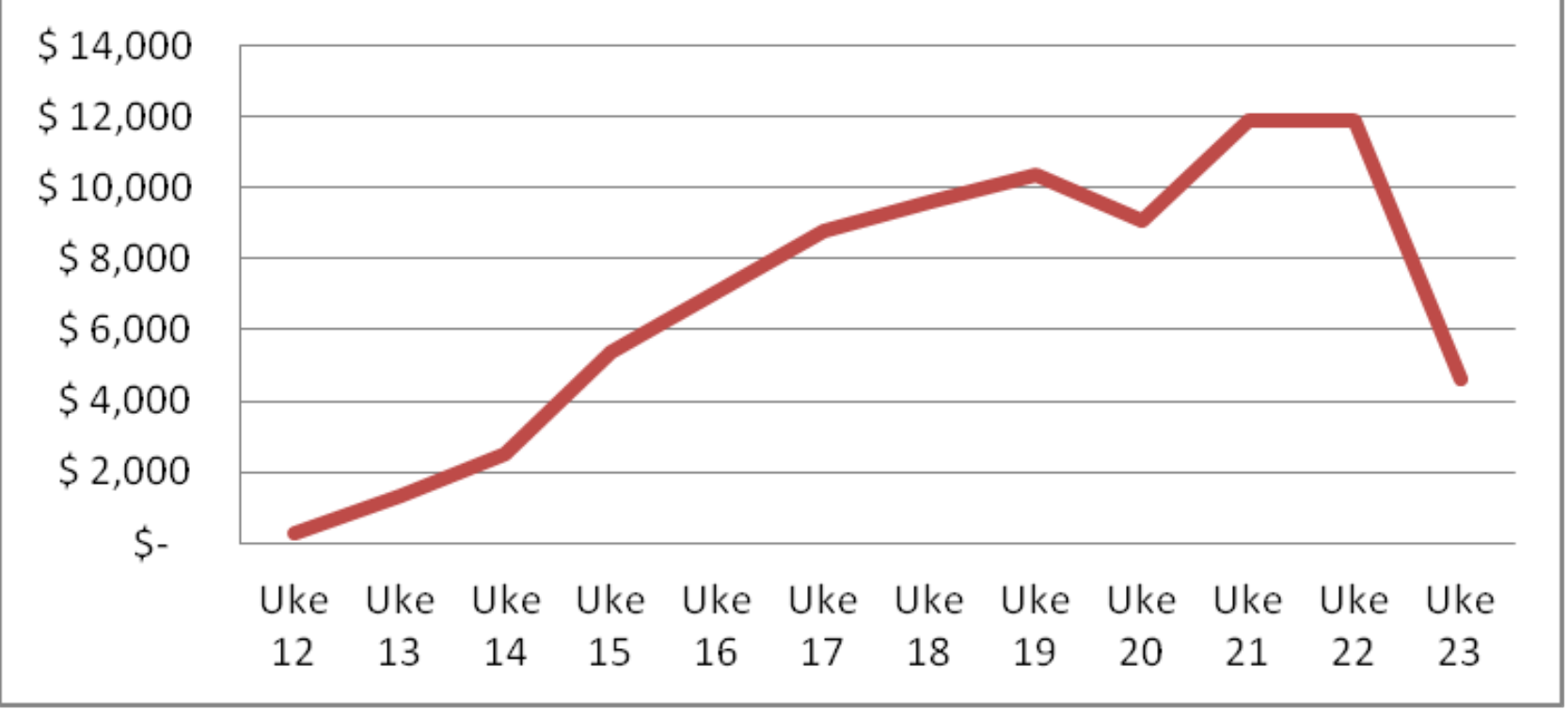

Figure 1: Weekly cost of user initiated purchases in US\$ from March 16 to June $1^{\text {st }} 2020$. (Svanberg - personal communication) 
Web pages:

Both the University and the Library set up special web pages for COVID-19 related information. The Library focused on what services would be available during the time when the library buildings were closed, and how to get access to literature and information.

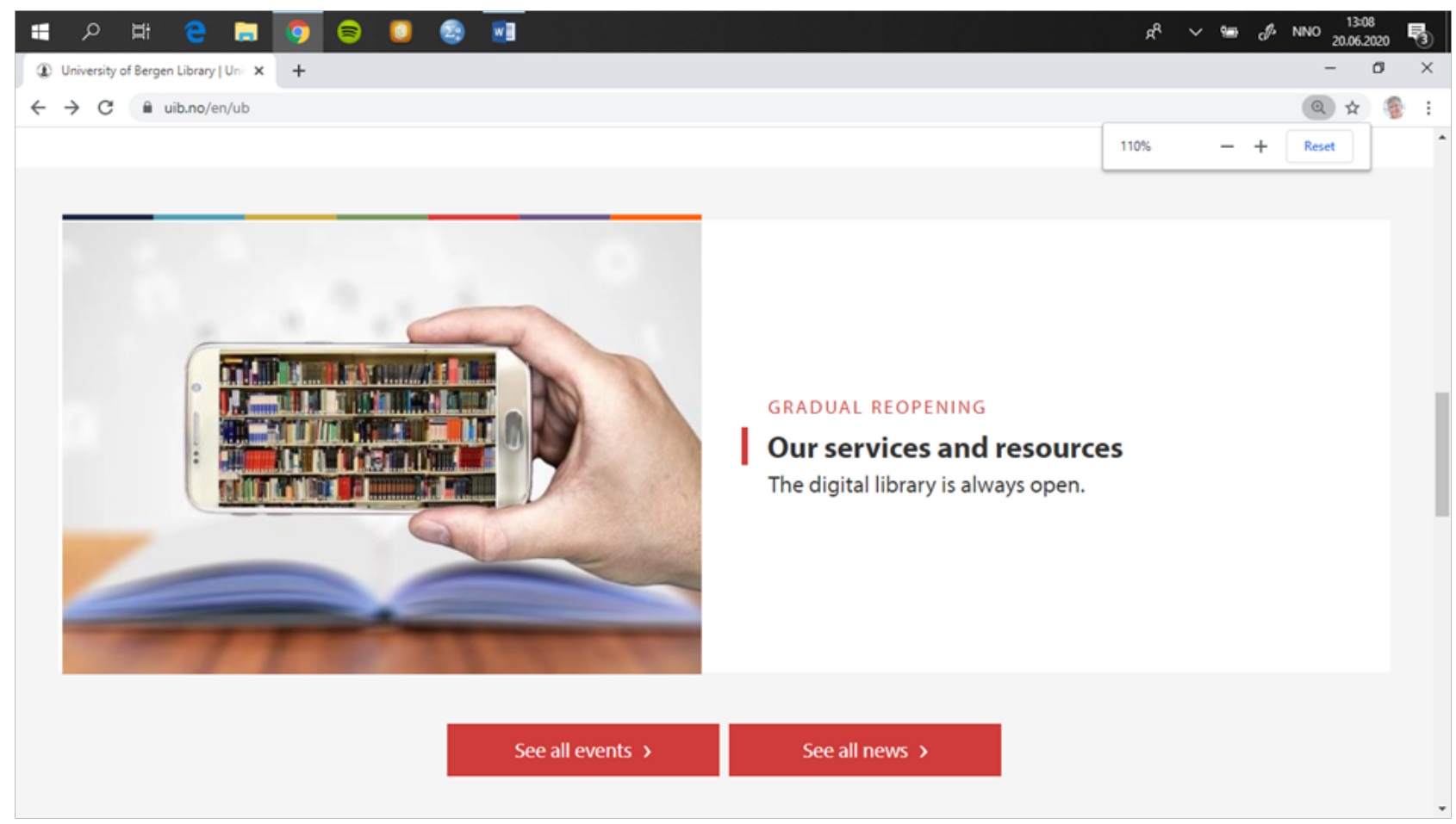

From March 12th to June 5th, 2020 there was a $137 \%$ increase in usage compared to the same period in 2019: from 60.590 page views in 2019 to 143.409 in 2020.

Chat:

As mentioned earlier, the Library chat services were under evaluation and had been temporarily suspended while one was testing out the new "UiB-help"-services. However, the software and the trained staff were still in place, and an initiative came from the library staff to re-open the chat and market the services more widely than before. There were 625 chat requests between March $12^{\text {th }}$ and June 5th, as compared to 247 in the same period in 2019, an increase of $153 \%$. An overview of the type of questions shows that most questions were concerning loans, returns, reservations and help in accessing journal articles. Also the open repository and other issues regarding open publishing, and support for using EndNote and other referencing tools/referencing question. The main user group, according to the type of questions, seem to be students.

UiB help is a relatively new service that aims to be a one-stop-shop for all kinds of questions, and the Library has responsibility for certain areas. There were approximately 50 requests through this service, mainly from university staff, and most of them concerning the digital study literature system Leganto which had deadline for information about courses in fall term 2020 from academic staff around May $1^{\text {st }}$ this year.

Feedback

E-mails to the libraries increased, and this was also due to the fact that the Library websites were amended, the phone numbers were removed and the e-mail addresses were put more prominently in place. One of special the email-addresses is accessed directly from the user interface of the library catalogue. This address saw an increase in issues between March 12th and June 5 th of $85 \%$, compared to the same period in 2019, from 333 to 615 . The main kind of questions were problems with access to electronic resources from outside campus. 
Shut up and write

The "Shut up and write!" sessions went digital to Zoom immediately after the library buildings closed, and was expanded to two sessions per week, one for PhDs and postdocs, and one also for staff and students. In addition, the academic librarian in charge opened for digital check in/ supervision every morning. According to feedback from the $\mathrm{PhDs}$, this service was beneficial to maintaining progression and a feeling of unity.

Also, referencing sessions with students were done digitally (over Zoom) and also by phone, which would "normally" happen face to face.

\section{Staff issues:}

The University was clear from the first days of closure that no-one was going to lose their job or be suspended, including here students working as library assistants, and project workers in the Special collections who normally tidy and move books and journals from stacks to stacks. As for many other workplaces the norm after March $12^{\text {th }}$ was office from home, with the Library buildings being physically closed to all, patrons and staff equally. This had its own set of challenges, with change of routines (especially for the approximately $50 \%$ of the library staff who normally work in the collections/with the books). Digital meetings and even conferences were set up and conducted over previously unknown and untested software.

After the first days of confusion and slight chaos had settled, employees were able to establish good routines that made it easier for the individual to solve the tasks from home. They were, for example, getting to know and mastering digital tools, establishing digital meeting points for professional meetings and exercising social community.

In the beginning, the home office was not optimal for different reasons. One challenge was to create a workplace with PC and monitor, extra display, ergonomically adapted tables, chair, mouse, webcam, headset, correct cables. Also, other problematic issues in the home office situation, including family (schools and kindergartens were also closed) infrastructure (furniture, computers and network/broadband) and tasks (not all employees had been doing tasks that could easily be transferred to a home office situation). This is equal to the situation in many other workplaces, both inside and outside the University.

After the employees brought home more adapted ICT and ergonomic equipment, the situation improved considerably, but still some worked under poor conditions with noise from the surroundings in the local area which made it difficult to work concentrated, others had poor broadband conditions.

The Library safety representatives (an elected office among the staff), sent out a working environment survey between 24 and 27 March, after approximately 10 days library closure. Most of the staff $(70 \%$ ) responded. $64 \%$ said they were fine or good; $31 \%$ said they were ok, and $5 \%$ found the situation challenging and frustrating.

In response to the open question: "How are you now?" the majority said, "fine", "good" or "ok", but most did also add words like "special", "surrealistic", "strange", "unreal", "scary", "sad", "boring", "empty", "challenging", or "chaotic". Among the positive comments are found "this is educational", "we learn new software and systems", "I have enough to do", "I have enough time", "I can handle the digital contact". The negative comments focus on "missing the contact with colleagues and students", "worry, isolation and sadness", "not enough tasks, not broadband, computers or other equipment", "difficult/challenging with children; home schooling and home kindergarten". This is in line with comments from other sectors as well. There is no proper research done on this in a Norwegian context yet, but it is widely reported in the media. (See f.ex Larsen 2020) 
Positive comments came also from the Library Director, who had an information post on the intranet every day, as the University leadership tried to cope with all challenges. On the other hand, among the responses to several open questions, 32 mentioned "missing colleagues". When asked about the level of follow-up from leaders, $67 \%$ (50 respondents) agree to "high level of follow-up" and $16 \%$ to some degree. $4 \%$ says "low degree", and $8 \%$ don't know.

This survey was followed by another, mapping the needs for computer equipment (laptops, screens, keyboards) and ergonomic equipment (chairs and other office equipment). Some of this were picked up from the library buildings, while others were new purchases, paid for by the Library. A few enterprising librarians also used the possibility to get into the buildings to take home all the books in the workflow, needing classification and cataloguing.

\subsection{Gradually reopening of the Library (April 20th to June 22nd)}

The Library started offering a «take-away»-service from April 20th, where patrons could request a book (or several) to be picked by library staff from the shelves, and prepared for pick-up at set times outside the library building. This continued until June 19th. The service was open only to patrons from $\mathrm{UiB}$, and only for books from own collections. Between April $20^{\text {th }}$ and June $19^{\text {th }}$ there were 4446 requests for loans, and 4140 went through. (between March 12th and April 19th there were no loans). In a normal year one would expect around 22.500 loans in the same period, so there were approximately $25 \%$ loans. This must be considered the absolutely most necessary for students and academics.

The service was launched on via UiB's corona website, student pages (My UiB), the Library's own website and social media such as Facebook and Instagram. A special infection control routine was created for handling the collections. This was at an early stage of the corona crisis, and there was great uncertainty about whether books were infected or not. In order to protect both employees and users against possible infection, it was important that as few persons as possible had physical contact with the book collections, and that the handover to the users took place as contactless as possible. Employees who had to return to campus and the libraries to perform the service had to be formally approved through a simple application with the HR director, in case of the necessity of infection detection.

The challenge for the Library was that the service was based on volunteers among the staff. There were many considerations: not being in one of the groups with higher risk; preferably not using public transport to get to work, knowledge of how to handle orders in ALMA (the library catalogue system), etc. Finally, there were about 25 employees who were in the scheme distributed across the 6 libraries.

Users could order available material from the Library's own collections via the webcatalogue, and Library staff prepared the orders by picking up from the collections, lending, and putting in a bag ready for collection. The users were notified by e-mail when and where material could be retrieved within a specified deadline $12-14$ Monday, Wednesday and Friday). Upon arrival at the library's main entrance, the user rang the library's desk phone, and the library employee came out and set the bag outside the main door. The user then retrieved the bag.

The reason for very limited opening hours for retrieval of ordered material was to have as little traffic to the campus as possible, and to avoid the rush hour traffic and public transport.

The service quickly became popular - hundreds of orders were already received in the first few days, especially book-heavy subjects at the Faculty of Social Sciences. The humanities and Law Library also experienced great demand for book material. It was a busy time for the few library staff at work. An estimated $75 \%$ of the ordered material was collected within the deadline. The scheme worked until 19th June. 
During this period, it was not possible to return books due to infection control, but if the students (especially the ones that left the city) needed to return books they were allowed. From May $18^{\text {th }}$ the possibility to return books was reopened with some restrictions.

Also from May $18^{\text {th }}$ the students were allowed access to specially prepared working places in the library building, with strict enforcement of the infection control rules. This entails more cleaning, more space around each seat, and librarians and security staff to supervise. In order to use the spaces the students had to apply, and to pass an infection control course in cough- and hand hygiene. Patrons could still not find books in the stacks themselves, but had to order and pick up by the door, also the students that were allowed to read in the library buildings.

From June $22^{\text {nd }}$ the library buildings are reopening with normal services for academics and UiB-students, and with shorter opening hours.

\section{Staff issues after gradually reopening}

When the government announced that from June 15th, staff and students could return to an open campus, the joy of staff and students looking forward to this was due to the physical, mental and social consequences they felt the home office brought. But many also did not think that the intention for employees to return to their offices before the summer to prepare for the fall semester was a particularly good idea. Alongside the concern about whether it was justifiable in terms of infection protection and unnecessary strain and use of public transport, it was also emphasized that home office is perceived as a more efficient way of working and which could also provide a health benefit. Employees felt that it was unnecessary to return to campus before the holidays because they were so well established at home with good routines for good job performance, and had the benefits of being able to work flexibly.

The University has always had a great deal of trust in its staff, and emphasizes the value of all the good work done from home offices in the state of emergency that is the COVID-19 crisis. For the employer, the challenge is that home office has not previously been the rule, but the exception. There are a number of laws and regulations drawn up by the Labour Inspectorate which applies when using a home office and which are enshrined in the Work Environment Act. For example, in addition to written agreements between the employee and the employer, it must take into account the working environment and facilities such as tables, chairs, computer mouse / keyboards, indoor climate, and not least safety when using equipment at home. Home office offers many opportunities, but also carries a risk, and among other things may pose a major security challenge for the Library and University.

Further use of home office for administrative and technical staff at UiB can be agreed with the nearest manager. In addition, UiB will start, together with the labour unions, investigating a future model for the use of home offices during parts of working hours for this group of employees.

4. Conclusions

The University of Bergen, like most other institutions of Higher Education in Norway, was not prepared for a pandemic. The Library had an updated risk-analysis and was well under way with intern control and contingency plans. They would eventually include pandemics. However, the Library and staff responded rapidly and decisively to this new and unforeseen situation. We expect that the Library will learn from the closed campus and that the leaders will be aware of the need for social interaction and combatting screen fatigue that may occur if staff is not encouraged to take breaks and go outside. 
Another of the changes that are predicted for library staff, as for the rest of the university and the public sector, will be less travel, including less public transport, more digital meetings, and also digital conferences. There will probably be more use of home office for those who can do their work from home, but this may lead to challenges, and also needs to take laws and regulations for worker welfare into account.

Also, there are positive experiences to students, academics and library staff: Mastering new digital tools and feeling more comfortable when working with them, both for meetings, supervisions and trainings.

We also imagine that COVID-19 will contribute to a more speedy shift in usage from printed to electronic books, especially among students. We believe that when the students are forced to use electronic books they will adapt. This is what has happened with electronic journals. Earlier, we have found indications that part of the preference for paper comes from the familiarity with the tools that can be used on paper (writing notes, underlining, and marking the text) (Gastinger, Landøy, Repanovici, 2015; Landøy, Færevaag, 2019)

On the other hand, a survey conducted in June 2020 shows that $30 \%$ of 1700 students state that they have learnt best by reading both printed and electronic materials, while $45 \%$ said they would like $75 \%$ of the reading material in paper format. This is astonishingly similar to the numbers from three years ago, even though the amount of digital books have multiplied during the last years (Svendsen 2020).

The students were asked how they were coping, and said they did not learn as much when they were only reading literature on a screen. In an open field in the survey, they said they missed libraries and other social meeting places (Svendsen 2020). 


\section{References}

BioCEED (2020) Student experience with the sudden shift to digital teaching, May 25, available: https://bioceednews.w.uib.no/2020/05/25/students-experience-with-the-sudden-shift-to-digitalteaching/ [accessed June $1^{\text {st }} 2020$ ]

CELL (2020) Online Teaching in the Time of COVID-19: Academics' experiences in Norway, April 16, available: https://www.jus.uio.no/cell/digitaldugnad/nasjonal_evaluering laerere.html [accessed June 1st 2020]

Gastinger, Almuth, Landøy, Ane and Repanovici, Angela (2015). The More they Tried it the Less they Liked it: Norwegian and Romanian Student's Response to Electronic Course Material In Kurbanoğlu, Serap [Eds.] Information Literacy: Moving Toward Sustainability, Springer, pp. 455-463, available: https://doi.org/10.1007/978-3-319-28197-1 46 http://hdl.handle.net/1956/12485

IFLA (2020) Understanding COVID-19 and its spread, September 1, available: https:// www.ifla.org/covid-19-and-libraries\#understanding [accessed June 1st 2020]

Larsen, H. (2020) Åpner for mange flere på kontorene [Opening for more staff back to the offices], June 19, available: https://khrono.no/apner-for-mange-flere-pa-kontorene/497925 [accessed June 25th 2020]

Svendsen, N. (2020) 6 av 10 lærer mindre med digital undervisning [6 of 10 learns less with digital teaching], June 24, available: https://khrono.no/6-av-10-laerer-mindre-med-digitalundervisning/498440 [accessed June 28th 2020]

Landøy, Ane, Færevaag, Trude (2019). Students' preferences for print vs electronic study literature - next step after the survey in Norway. Qualitative and Quantitative Methods in Libraries electronic journal 8 (1) pp. 125-131, available: http://hdl.handle.net/1956/19862 [accessed June 15th 2020].

Mizrachi, D. Salaz, A. M. Kurbanoglu, S. and Boustany, J. (2018) Academic reading format preferences and behaviors among university students worldwide: A comparative survey analysis. PLOS ONE. 2018, 13 (5), available: https://doi.org/10.1371/journal.pone.0197444 http:// hdl.handle.net/1956/18032

National Library of Norway (2020) Korona - informasjon til bibliotekene [Corona - information for libraries], available at: https://bibliotekutvikling.no/korona/ [accessed June 10th 2020].

NBF (2020) Smittevernveileder for bibliotek [Infection control guide for libraries], available: https://norskbibliotekforening.no/2020/05/smittevernveileder-for-bibliotek/[accessed June 10th 2020].

Støren, Liv Anne and Nesje, Kjersti. (2018) Kandidatundersøkelsen 2017: Nyutdannede masteres møte med arbeidslivet og vurdering av relevans, studiekvalitet og læringsutbytte[The Candidate survey 2017: Newly created Masters' encounter with the working life and evaluation of relevance, study quality and learning outcome]. NIFU-rapport, 22, available: http:// hdl.handle.net/11250/2558181 [accessed June 10th 2020].

UiB (2020) Flertall ved UiB-institutt mener studiekvaliteten har falt under korona [The majority at the UiB institute belives that the quality of studies has fallen during the corona], available: https:// pahoyden.no/flertall-ved-uib-institutt-mener-studiekvaliteten-har-falt-under-korona/488150 [accessed June 10th 2020]

UiB (2020) Facts about the library, available: https://www.uib.no/en/ub/79532/facts-aboutlibrary\#general-information [accessed June $10^{\text {th }} 2020$ ]. 